\title{
ISSN:
}

Print - $2277-0755$

Online - $2315-7453$

(C) FUNAAB 2020

\author{
Journal of \\ Agricultural \\ Science \\ and Environment
}

\section{IMPACT OF HUMAN-WILDLIFE CONFLICT IN THE SURROUNDING VILLAGES OF OLD OYO NATIONAL PARK}

\author{
A. L. A. SHOTUYO, O. A. AKINTUNDE AND F. G LANLEHIN
}

Department of Forestry and Wildlife Management, Federal University of Agriculture, Abeokuta, Nigeria

*Corresponding Author: shotuyoala@funaab.edu.ng, Tel: +23408033455902

\begin{abstract}
The study assesses the impacts of Human-Wildlife conflicts in the surrounding villages in Old Oyo National Park (OONP), Nigeria. Two ranges out of the five ranges were used. Four villages were selected based on the distribution of primates and wildlife populations with each range producing two villages around Old Oyo National Park, were randomly selected for wildlife assessment. A total of 80 well-structured questionnaires were administered to the villagers with each getting 20 questionnaires respectively. Data collected were subjected to inferential and descriptive statistics. Result shows that among other socio demographic characteristics tested against the impact of Human -wildlife conflict in the park, educational level and religion show significant difference $(p<0.05)$. the buffer zone around the park has been extensively encroached; this made most of the surrounding villages to the park fall within the average distance of $2.6 \mathrm{~km}$. about $79 \%$ of the villages make use of fire wood for their household cooking. Major animals that intrude farmlands in the study areas include monkey (24\%), Grasscutter $(11 \%)$, Cattle (19\%), Gorilla (12\%), Antelope $(6 \%)$, Cane rat $(5 \%)$ and Rabbit $(3 \%)$. Some of the crops attacked by the wildlife animals include; tubers $(24 \%)$, tubers and vegetable $(7 \%)$, tubers and fruits $(36 \%)$, tubers, vegetable and fruits $(3 \%)$, vegetable $(7 \%)$, fruits $(3 \%)$. All the respondents $(100 \%)$ rated the level of attack and damages to their crops as high.
\end{abstract}

\section{INTRODUCTION}

National Parks are refuges of tranquillity and peace, yet they are also places where conflict occurs. In a world in which the biophysical environment and socio-cultural system are changing rapidly, conflicts involving protected areas are unavoidable. However, conflicts that are properly addressed can be opportunity for problem to be identified and solved. In the Nineteenth and early part of twentieth century, most African countries were colonized by Europeans, who set apart large areas of land containing wildlife and other natural resources for conservation under state ownership. Thus, colonial government owned relatively high-density of wildlife areas in many parts of Africa. Rural communities with traditional custodians of wildlife resources were forcibly moved out of their ancestral areas of land and consequently alienated from the wildlife that they once owned.

Human-wildlife conflict is defined as "any interaction between humans and wildlife that results in negative impacts on human social, economic or cultural life, on the conservation of wildlife populations, or on the envi- 
ronment" (WWF 2005). Conflicts between villages sharing border with the Old Oyo humans and wildlife are the product of National Park which has resulted to Humansocio-economic and political landscapes and Wildlife conflict over the years. This study is are controversial because the resources concerned have economic value and the species involved are often high profile and legally protected (Treves and Karanth 2003; McGregor 2005). While humans and wildlife have co-existed for millennia, the frequency of conflicts involving problem animals as grown in recent decades, mainly because of the exponential increase in human populations and consequential expansion of human activities (Woodroffe 2000; Woodroffe et al. 2005), expansion of wildlife distributions, as well as a frequent inability of institutions that are meant to mediate such conflicts to respond effectively.

Conflicts between wildlife and human are a major conservation problem which conservation organizations all over the world are dealing with (WCS, 2010). Human wildlife conflict is one of the major threats to conservation in Africa. They occur in different settings such as increasing land scarcity, hunting prohibition and wildlife induced damage to property and these constitute factors that may create local hostility towards wildlife and protected areas. Access to land is a central issue in rural Africa for both farmers and pastoralists. Consequently, rural Africans generally do not want to give up land to wildlife or have wildlife nearby (Newmark et al., 1994). One major source of conflict between wildlife and farmers in Nigeria and the world at large is crop raiding (Rowe, 1996; Hill et al., 2004; Warren, 2003 and Distefano, 2010).

This study will therefore assess the effects and impacts of wildlife's activities on two

therefore carried out to specifically:

- Determine the effect of Primate and other wildlife on the livelihood of residence in the two villages under study that share boundary with the park.

- Determine percentage damage done to farms produce by primates and any other related species.

- Determine perception on the conservation of wild animals.

- Determine the causes of human wildlife conflict

- Determine the challenges of the respondents in the study area.

- Determine and make recommendation on how to combat conflict in the study area.

\section{METHODOLOGY}

\section{Study Area}

The study was carried out in villages bordering Old Oyo National park, Nigeria. Old Oyo National Park (OONP) is one of the National parks of Nigeria. The Park stretched through Guinea and derived savannah. The park lies between latitude $8^{\circ} 15^{\prime}$ and $9^{\circ}$ north; and longitude $3^{\circ} 35^{\prime}$ and $4^{\circ} 42^{\prime}$ east and covers a total area of $2,512 \mathrm{~km}^{2}$ mostly of lowland plains at a height of $330 \mathrm{~m}$ and 508 $\mathrm{m}$ above sea level. The Climate is equatorial, notably with dry and wet seasons with relatively high humidity. The dry season lasts from November to March while the wet season starts from April and ends in October. Average daily temperature ranges between 25 ${ }^{\circ} \mathrm{C}\left(77.0{ }^{\circ} \mathrm{F}\right)$ and $35{ }^{\circ} \mathrm{C}\left(95.0^{\circ} \mathrm{F}\right)$, almost throughout the year. 


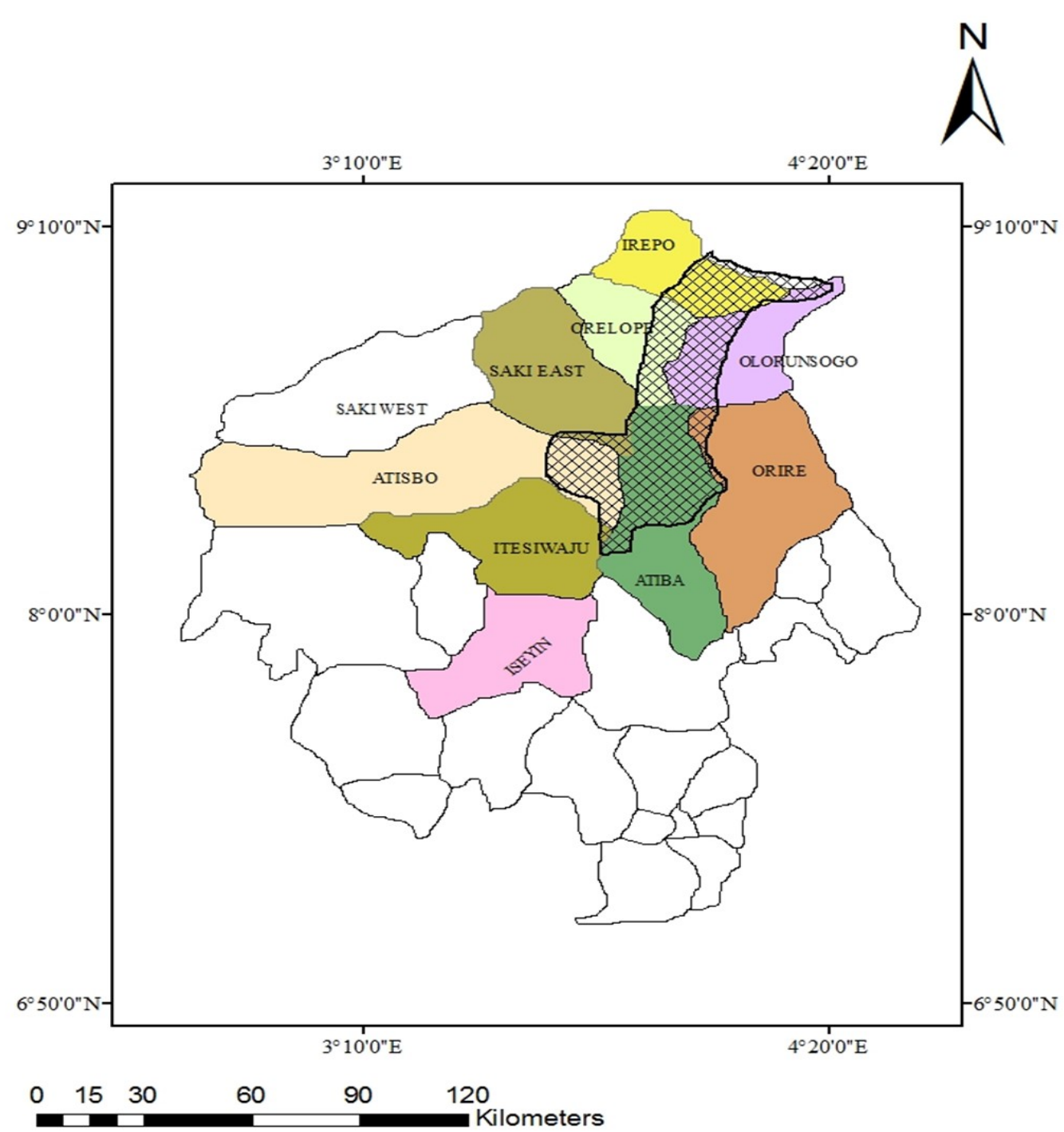

$1: 1,500,000$

Legend

OLD OYO NATIONAL PARK

Fig 1. A map showing the Old Oyo National Park, Oyo and its surrounding town

Old Oyo National Park comprises of a study based on the impact of Human - wildwhole lot of communities bordering the 5 life conflict in the surrounding villages in ranges (which are: Oyo Ile, Sepeteri, Tede, Old Oyo National park. They are: Marguba Yemoso and Marguba Ranges) of the park. Range (comprising of Abanla and Imodi vilHowever, only two ranges was used for this lages) and Sepeteri Range (comprising of 
Budo Alhaji and Fomu villages). Thus the four villages mentioned were used for the study.

\section{Sampling Procedure and Sample Size}

The study was carried out using a well structure questionnaire to villagers around the four communities sharing boundary with the range selected. A total of eighty (80) copies of the questionnaire were administered to the respondents in the four selected four selected village, with twenty (20) questionnaire randomly administered to household representatives in each respectively.

\section{Method of Data Collection}

The required primary data and information were collected through the use of copies of a well structured questionnaire designed to suit the objective of the study especially the specific objective of the study.

\section{Analytical tools}

Computer analysis with Statistical Package for the Social Sciences (SPSS) software was used. Descriptive statistics of the data collected were also represented in tables and charts.

\section{RESULTS AND DISCUSSION Socio Economic Characteristics of Re- spondent}

The age distribution of the respondents shows that $23.8 \%$ are within the ages of 20 30 years, $28.7 \%$ are within $31-40$ years, $40.0 \%$ are within $41-50$ years, while $7.5 \%$ are above 50 years (Table 1). This indicates that majority of the farmers are within the agricultural productive age of between 20 and 40 years. This also conforms with the findings of Oduntan et al., (2008), that people between 20 and 40 years of age are en- gaged in agriculture. The gender distribution shows that $45.0 \%$ of the respondents are male, while $55.0 \%$ are female. This is in line with the earlier findings of Oduntan et al (2008). The marital distribution shows that $28.7 \%$ of the respondents are single, $70.0 \%$ are married, while $1.3 \%$ of the respondent is divorced. The religion distribution of the respondents, shows that $56.3 \%$ are Christian, $42.5 \%$ Islam, $1.3 \%$ traditional. This can be attributed to the large number of churches in the study area. The educational distribution of the respondents, the table shows that $68.8 \%$ of the respondents had no formal education, $23.8 \%$ of the respondents had primary education, $2.5 \%$ had secondary education, while $5.0 \%$ had tertiary education. This result agrees with the earlier findings of Oduntan et al., (2008) who noted that majority of the respondents in the study area were without formal education. Past researchers have found that farmers with formal or higher education level are more likely to recognize and be cautious of harmful environmental practices or pest control methods (Jacobson et al., 2006). The household size distribution of the respondents, the table shows that $71.3 \%$ of the respondents had a household size of between 2-5, while $28.7 \%$ of the respondents had a household size between 6-10. Previous studies (Akinyemi and Oduntan, 2004; Oduntan et al., 2012) revealed that families with many members will likely have more economic pressure and struggling to uplift their living standard.

The occupation distribution of the respondents, the table shows that majority $77.5 \%$ of the respondents are farmers, $8.8 \%$ of the respondent are artesian, $6.3 \%$ are hunters, while $7.5 \%$ of the respondents are civil servants. farming is said to be the predominant occupation in the rural communities which accounted for the large number of respon- 
IMPACT OF HUMAN-WILDLIFE CONFLICT IN THE SURROUNDING VILLAGES...

dents who are into agriculture due to ad- income level between N20000 and N30000, verse land area and vegetation. The income while $30.0 \%$ of the respondents earns an indistribution of the respondents, the table come level above 30000. This is due to the below shows that $25.0 \%$ of the respondents predominant occupation of the respondents earns an income level between N5000 and in the study area who are farmers and prac$\mathrm{N} 10000,10.0 \%$ earns an income level be- tice subsistence farming, providing for their tween N10000 and N20000, 35.0\% earns an family first before selling.

Table 1: Distribution of Respondents Socio-economic Characteristics

\begin{tabular}{|c|c|c|c|}
\hline Variable & Classes & $\mathbf{F}$ & $\%$ \\
\hline \multirow[t]{5}{*}{ Age } & 20-30years & 19 & 23.8 \\
\hline & 31-40years & 23 & 28.7 \\
\hline & 41-50years & 32 & 40.0 \\
\hline & Above 50years & 6 & 7.5 \\
\hline & Total & 80 & 100.0 \\
\hline \multirow[t]{3}{*}{ Gender } & Male & 36 & 45.0 \\
\hline & Female & 44 & 55.0 \\
\hline & Total & 80 & 100.0 \\
\hline \multirow[t]{4}{*}{ Marital Status } & Single & 23 & 28.7 \\
\hline & Married & 56 & 70.0 \\
\hline & Divorced & 1 & 1.3 \\
\hline & Total & 80 & 100.0 \\
\hline \multirow[t]{4}{*}{ Religion } & Christianity & 45 & 56.3 \\
\hline & Islam & 34 & 42.5 \\
\hline & Traditional & 1 & 1.3 \\
\hline & Total & 80 & 100.0 \\
\hline \multirow[t]{5}{*}{ Educational Level } & No Formal Education & 55 & 68.8 \\
\hline & Primary & 19 & 23.8 \\
\hline & Secondary & 2 & 2.5 \\
\hline & Tertiary Education & 4 & 5.0 \\
\hline & Total & 80 & 100.0 \\
\hline \multirow[t]{3}{*}{ Household Size } & $2-5$ & 57 & 71.3 \\
\hline & $6-10$ & 23 & 28.7 \\
\hline & Total & 80 & 100.0 \\
\hline \multirow[t]{5}{*}{ Occupation } & Farming & 62 & 77.5 \\
\hline & Artesian & 7 & 8.8 \\
\hline & Hunting & 5 & 6.3 \\
\hline & Civil Servant & 6 & 7.5 \\
\hline & Total & 80 & 100.0 \\
\hline
\end{tabular}




\section{Distribution of the type of Crop Grown and Crops Attacked by Wild Animals}

According to the type of crops grown. $12.5 \%$ of the respondents grow tubers, $18.8 \%$ of the respondents grow tubers and vegetables, $38.8 \%$ of the respondents indicated they grow tubers and fruits (Table 2). About $23.8 \%$ of the respondents indicated they grow tubers, fruits and vegetables, $5.0 \%$ indicated that they grow vegetables, while $1.3 \%$ of the respondents indicated they grow fruits only. The respondents in the study area are predominantly farmers that grows mainly tubers and fruit such as cassava, maize which is a priority crop cultivated by all the farmers in the study area. The distribution of respondents according to the crops attacked by wild animals, $30.0 \%$ of the respondents indicated that tubers were usually attack by wild animals, $8.8 \%$ indicated that tubers and vegetables were usually attacked, $45.0 \%$ indicated that tubers and fruits were attacked, $3.8 \%$ indicated that tubers, fruits and vegetables were usually attacked, $8.8 \%$ indicated that only vegetables were attacked, while $3.8 \%$ of the respondents indicated that only fruits were attacked. These findings agree with the observations of some previous studies (Else, 1991; Naughton-Treves, 1998 and Naughton -Treves et al., 1998; Shemweta and kidegesho, 2000; Waladji and Tchamba, 2003) that raiding which affects Maize occurred when ripe Maize is available. The impact of Maize destruction is most felt by households. Tantalus monkeys were implicated for most destruction done to Maize in Filinga range. Similarly, Shemwata and Kidegesho (2000) listed Warthog, Tantalus monkey and porcupine among the major cause of crop damages to the local communities around the Seakale Swayne hartebeest sanctuary in Ethiopia. Maize is a priority crop cultivated by all the farmers in the study area. Destruction of a priority crop in a community where about $80 \%$ of the people are engaged in agriculture (Kirk - Green, 1958) is a very serious case that requires an urgent attention to safe the entire populace from hardship as respondents' economies are negatively affected.

Table 2: Distribution of Respondents according to the Type of Crop Grown and Crops Attacked by Wild Animals in all the selected villages

\begin{tabular}{lllr}
\hline QUESTION & F & $\mathbf{\%}$ \\
\hline Type of crops & Tubers (cassava, yam, potatoes) & 10 & 12.5 \\
grown by house- & Tubers and vegetables & 15 & 18.8 \\
holds in study area & Tubers and fruits & 31 & 38.8 \\
& Tubers, fruits and vegetables & 19 & 23.8 \\
& Vegetables (tomatoes, pepper, okro, mellon) & 4 & 5.0 \\
& Fruits (mango, cashew, maize, cheery, groundnut) & 1 & 1.3 \\
& Total & 80 & 100.0 \\
What are the & Tubers (cassava, yam, potatoes) & 24 & 30.0 \\
crops usually at- & Tubers and vegetables & 7 & 8.8 \\
tacked by wild & Tubers and fruits & 36 & 45.0 \\
animals & Tubers, fruits and vegetables & 3 & 3.8 \\
& Vegetables (tomatoes, pepper, rodo, okro, mellion) & 7 & 8.8 \\
& Fruits (mango, cashew, maize, cheery, groundnut) & 3 & 3.8 \\
& Total & 80 & 100.0 \\
\hline
\end{tabular}


IMPACT OF HUMAN-WILDLIFE CONFLICT IN THE SURROUNDING VILLAGES...

Distribution of respondents according to the Species of Wildlife Animals visiting their Farm and the Rate of Destruction caused by Wildlife Animals

About $26.3 \%$ of the respondents indicated that monkeys do visit their farm, $13.6 \%$ of the respondents indicated that grasscutter visits their farm, $23.8 \%$ of the respondents indicated that their farms are visited by cattle, $15.0 \%$ indicated that Gorilla visits their farm, $6.3 \%$ indicated that giant rat are visitors to their farm, $3.8 \%$ indicated that rabbit visits their farm, $7.5 \%$ indicated that their farm are visited by antelope, $3.8 \%$ of the respondents indicated that rabbits do visit their farm (Table 3). This is partly in line with the findings of Warren (2003) that primates reduce $42.1 \%$ of expected crop yield in the study area. It also corroborates other studies (Naughton-Treves, 1998; Porter and Sheppard, 1998 and Yudelman et al., 1991) that estimated losses caused by primates to be between $10-50 \%$ of total crop production.

Majority of the respondents indicated that the cause of destruction by wild animals is high. This corroborates with Oduntan et al (2009) who concluded that destruction of crop by wild animal species hardened farmers' attitude against wildlife conservation. Loss of thousands and millions of Naira of food crops in villages of a nation where $70.80 \%$ of the population are living on less than one dollar a day and $92.40 \%$ on less than two dollars a day (UNICEF, 2006) can further impoverished people living in such areas.

Table 3: Distribution of respondents according to the Species of Wildlife Animals visiting their Farm and the Rate of Destruction caused by Wildlife Animals in the selected villages

\begin{tabular}{llrr}
\hline QUESTION & & F & \% \\
\hline What species of wildlife animal visit & Monkey & 24 & 40.1 \\
your farm & Grass cutter & 11 & 13.9 \\
& Cattle & 19 & 23.8 \\
& Gorilla & 12 & 15.0 \\
& Giant rat & 5 & 6.3 \\
& Rabbit & 3 & 3.8 \\
& Antelope & 6 & 7.5 \\
& Total & 80 & 100.0 \\
How you rate the level of destruction & High & 80 & 100.0 \\
caused by wildlife animals & Medium & 0 & 0.0 \\
& Low & 0 & 0.0 \\
& Total & 80 & 100.0 \\
\hline
\end{tabular}


Perception of Respondents on the Conservation of Wildlife animals

About 5\% of the respondents strongly agree that they are not permitted to kill the wild animals, majority containing about $62.5 \%$ of the respondents agrees that they are not permitted to kill wild animals, $32.5 \%$ disagrees that they are not permitted to kill the wild animal (Table 4). This conforms to the findings from Pers. Com. (2010), which noted that discussants emphasized that "Wild animals especially Kirka (Tantalus Monkeys) has disturbed their village for a long time as they are not permitted to kill the animals. About $63 \%$ of the respondents strongly agree that the animals are not useful to them because they don't eat their meat, $61.3 \%$ strongly disagree, while $32.5 \%$ disagree with the opinion.

About $51.2 \%$ of the respondents strongly agree that animals are usually active around farm settlement, $32.5 \%$ agree, $\quad 11.3 \%$ strongly disagree, while $5.0 \%$ disagree. This is due to the fact that they are attracted to the farm settlement due to the presence of crops which serves as food to them. Also $51.2 \%$ of the respondents strongly agree that beneficiaries of these wild animals are tourists and park management, $36.3 \%$ agree, $6.3 \%$ strongly disagree, while $6.3 \%$ disagree. Also, $56.3 \%$ of the respondents strongly agree that they learn to tolerate wildlife animals around them, 36.3\% agree, 3.8\% strongly disagree, $3.8 \%$ disagree. About 55\% of the respondents strongly agree that the wild animals pose as treat to their farm produce, $37.5 \%$ agree, $3.8 \%$ strongly disagree, $3.8 \%$ disagree. This result supports the findings of Msiska (2002); Nxumayo et al. (2008) that noted that historical background of these communities is characterised by a general dissatisfaction with reserve authorities in part due to village evictions and damage to crops and property caused by wildlife.

About $56.3 \%$ of the respondents strongly agree that the animals (wild) cause economic loss to them as their livelihood is destroyed, $36.3 \%$ agree, $3.8 \%$ strongly disagree to the opinion, while $3.8 \%$ disagree. This supports the findings of (UNICEF, 2006) that there is loss of thousands and millions of Naira of food crops in villages of nations that are within wildlife parks and reserve, where $70.80 \%$ of the population are living on less than one dollar a day and $92.40 \%$ on less than two dollars a day.

Table 4: Distribution of Respondents according to Crops not usually attack by Wildlife Animals, and Their Sources of Domestic Energy

\begin{tabular}{llrr}
\hline QUESTION & F & \multicolumn{2}{c}{$\%$} \\
\hline What are the crops not usually attacked by wildlife ani- & No crop & 68 & 85.0 \\
mals & Tomatoes & 4 & 5.0 \\
& Potatoes & 5 & 6.3 \\
& Pepper & 3 & 3.8 \\
What are the sources of domestic energy to villagers & Total & 80 & 100.0 \\
& Firewood & 79 & 98.8 \\
& Charcoal & 1 & 1.3 \\
& Kerosene & 0 & 0.0 \\
& Total & 80 & 100.0 \\
\hline
\end{tabular}


IMPACT OF HUMAN-WILDLIFE CONFLICT IN THE SURROUNDING VILLAGES...

Table 5: Distribution of respondents according to their perception on the conservation of wildlife animals

\begin{tabular}{llllll}
\hline RESEARCH QUESTION & SA & A & SD & D & TOTAL \\
& F(\%) & F(\%) & F(\%) & $\begin{array}{l}\text { F(\%) } \\
\text { F(\%) }\end{array}$ \\
\hline $\begin{array}{l}\text { We are not permitted to kill the wild } \\
\text { animals }\end{array}$ & $4(5.0)$ & $50(62.5)$ & - & $26(32.5)$ & $80(100.0)$ \\
$\begin{array}{l}\text { The animals are not useful to us be- } \\
\text { cause we don't eat their meat }\end{array}$ & $5(6.3)$ & - & $49(61.3)$ & $26(32.5)$ & $80(100.0)$ \\
$\begin{array}{l}\text { Animals are usually active around } \\
\text { farm settlement }\end{array}$ & $41(51.2)$ & $26(32.5)$ & $9(11.3)$ & $4(5.0)$ & $80(100.0)$ \\
$\begin{array}{l}\text { Beneficiaries of these wild animals } \\
\text { are tourists and park management }\end{array}$ & $41(51.2)$ & $29(36.3)$ & $5(6.3)$ & $5(6.3)$ & $80(100.0)$ \\
$\begin{array}{l}\text { We learn to tolerate wildlife animals } \\
\text { around us }\end{array}$ & $45(56.3)$ & $29(36.3)$ & $3(3.8)$ & $3(3.8)$ & $80(100.0)$ \\
$\begin{array}{l}\text { They pose as treat to our farm pro- } \\
\text { duce }\end{array}$ & $44(55.0)$ & $30(37.5)$ & $3(3.8)$ & $3(3.8)$ & $80(100.0)$ \\
$\begin{array}{l}\text { They cause economic loss to use as } \\
\text { our livelihood is destroyed }\end{array}$ & $45(56.3)$ & $29(36.3)$ & $3(3.8)$ & $3(3.8)$ & $80(100.0)$ \\
\hline
\end{tabular}

Perception of respondents on the causes of human wildlife conflicts

About $47.5 \%$ of the respondents strongly agree that there is illegal hunting of wildlife, $28.7 \%$ agree, $16.3 \%$ strongly disagree, while $7.5 \%$ disagree to illegal hunting of wildlife (Table 6). This conforms to the findings of Kepe, et al (2000) that noted that illegal hunting is high because communities living around the protected area poach to supplement their starch based diet with protein as reported about in Mkambati Nature Reserve in South Africa. About $47.5 \%$ of the respondents strongly agree to illegal grazing of Park Range by cattle, $27.5 \%$ agree, $18.8 \%$ strongly disagree, while $6.3 \%$ disagree to illegal grazing of Park Range by cattle. Also, $46.3 \%$ of the respondents strongly agree to farmland encroachment by wildlife animal, $28.7 \%$ agree, $16.3 \%$ strongly disagree, $8.8 \%$ disagree to farmland encroachment by wildlife animal. This corroborates the findings of other studies (Naughton-Treves, 1998; Porter and Sheppard, 1998 and Yudelman et al., 1991) that estimated losses caused by primates to be between $10-50 \%$ of total crop production. Also $46.3 \%$ of the respondents strongly agree logging activities in park vegetation, $28.7 \%$ agree, $15.0 \%$ strongly disagree, while $10.0 \%$ disagree. About $51.2 \%$ of the respondents strongly agree that there is unemployment of villagers, $30.0 \%$ agree, $10.0 \%$ strongly disagree, while $8.8 \%$ disagree. The damage of crops which serves as livelihood could eventually lead to unemployment of productive youths. About $50 \%$ of the respondents strongly agree that destruction of farm crops were made by wildlife animals, $30.0 \%$ agree, $10.0 \%$ strongly disagree, $10.0 \%$ disagree. This is in line with studies of (Happold 1995; Emerton 1999; Choudhury 2004; Dublin and Hoare 2004; Hill et al 2004; Graham et al. 2005) who observed that wildlife damage represents a very real and tangible threat to livelihoods in terms of personal injury, crop and livestock losses, and property damage. 
About $31.3 \%$ of the respondents strongly mals to farmland by park management. agree that there is poor communication and understanding between the park management and surrounding communities, $25.0 \%$ agree, $31.3 \%$ strongly disagree, $12.5 \%$ disagree. This was attributed to lack of compensation given to farmers and rural dwellers for the damages caused by wildlife aniAbout $48.8 \%$ of the respondents strongly agree that park range boundaries are too close to surrounding communities, $22.5 \%$ agree, $18.8 \%$ strongly disagree, while $10.0 \%$ disagree. Findings indicate that majority of the communities in the study area share boundaries with the park.

Table 6: Distribution of respondents according to their perception on the causes of human wildlife conflicts

\begin{tabular}{|c|c|c|c|c|c|}
\hline RESEARCH QUESTION & $\begin{array}{l}\text { SA } \\
F(\%)\end{array}$ & $\begin{array}{l}A \\
F(\%)\end{array}$ & $\begin{array}{l}\text { SD } \\
F(\%)\end{array}$ & $\begin{array}{l}D \\
F(\%)\end{array}$ & $\begin{array}{l}\text { TOTAL } \\
\text { F(\%) }\end{array}$ \\
\hline Illegal hunting of wildlife & $38(47.5)$ & $23(28.7)$ & $13(16.3)$ & $6(7.5)$ & $80(100.0)$ \\
\hline $\begin{array}{l}\text { Illegal grazing of park range } \\
\text { by cattle }\end{array}$ & $38(47.5)$ & $22(27.5)$ & 15(18.8) & $5(6.3)$ & $80(100.0)$ \\
\hline $\begin{array}{l}\text { Farmland encroachment by } \\
\text { wildlife animal }\end{array}$ & $37(46.3)$ & $23(28.7)$ & $13(16.3)$ & $7(8.8)$ & $80(100.0)$ \\
\hline $\begin{array}{l}\text { Logging activities in park } \\
\text { vegetation }\end{array}$ & $37(46.3)$ & $23(28.7)$ & $12(15.0)$ & $8(10.0)$ & $80(100.0)$ \\
\hline Unemployment of villagers & $41(51.2)$ & $24(30.0)$ & $8(10.0)$ & $7(8.8)$ & $80(100.0)$ \\
\hline $\begin{array}{l}\text { Destruction of farm crops by } \\
\text { wildlife animals }\end{array}$ & $40(50.0)$ & $24(30.0)$ & $8(10.0)$ & $8(10.0)$ & $80(100.0)$ \\
\hline $\begin{array}{l}\text { Poor communication and un- } \\
\text { derstanding between the park } \\
\text { management and surrounding } \\
\text { communities }\end{array}$ & $25(31.3)$ & $20(25.0)$ & $25(31.3)$ & $\begin{array}{l}10 \\
(12.5)\end{array}$ & $80(100.0)$ \\
\hline $\begin{array}{l}\text { Park range boundary too } \\
\text { close to surrounding commu- } \\
\text { nities }\end{array}$ & $39(48.8)$ & $18(22.5)$ & $15(18.8)$ & $8(10.0)$ & $80(100.0)$ \\
\hline
\end{tabular}


Assessment of Impacts of Human Wildlife Conflicts on Respondents

About $48.8 \%$ of the respondents strongly agree that there is decrease in revenue from crop damaged, $16.3 \%$ agreed, $11.3 \%$ strongly disagree, while $11.3 \%$ disagree, (table 7). This can be attributed to the damage of crops and farmland by wild animals which have lead to reduction in revenue for dwellers around the park. This finding corroborates with the report of (UNICEF, 2006) that noted that loss of thousands and millions of Naira of food crops in villages of a nation where $70.80 \%$ of the population are living on less than one dollar a day and $92.40 \%$ on less than two dollars a day due to wildlife attacks on farmland. Also 46.3\% of the respondents strongly agree that there is an increase risk of starvation as there is no food due to loss of farm produce, $17.5 \%$ agree, $27.5 \%$ strongly disagree, $8.8 \%$ disagree. This finding indicates that due to massive damages encountered by farmers' food shortage is imminent as majority of their crops are destroyed. This is partly in line with the findings of Warren (2003) that primates reduce $42.1 \%$ of expected crop yield in the study area. It also corroborates other studies (Naughton-Treves, 1998; Porter and Sheppard, 1998 and Yudelman et al., 1991) that estimated losses caused by primates to be between $10-50 \%$ of total crop production.

About $50 \%$ of the respondents strongly agree that raising orphans is difficult due to conflict incidents, $15.0 \%$ agree, $28.7 \%$ strongly disagree, $6.3 \%$ disagree. This result indicates that damages to farmland implies damage to livelihood, thereby making it difficult for people who are raising orphans in their household due to the cost of living which is not commiserate with the income generated. Moreover $50.0 \%$ of the respondents strongly agree that residue from crops is not returned to soil as fertilizer when they are eaten, $15.0 \%$ agree, $30.0 \%$ strongly disagree, $5.0 \%$ disagree. These findings indicate majority of the crops attacked are taken away by the wildlife into the park and even their faeces which should have served as fertilizer is deposited in the park not the farmland.

About $53.8 \%$ of the respondents strongly agree that means of livelihood of villagers is destroyed, $17.5 \%$ agree, $22.5 \%$ strongly disagree, $6.3 \%$ disagree. This is in line with studies of (Happold 1995; Emerton 2001; Choudhury 2004; Dublin \& Hoare 2004; Hill 2004; Graham et al. 2005) who observed that wildlife damage represents a very real and tangible threat to livelihoods in terms of personal injury, crop and livestock losses, and property damage.

About $53.8 \%$ of the respondents strongly agree that there is extinction of wildlife animals due to hunting and indiscriminate killing, $18.8 \%$ agree, $17.5 \%$ strongly disagree, $10.0 \%$ disagree. Also $55.0 \%$ of the respondents strongly agree it creates unemployment, $21.3 \%$ agree, $13.8 \%$ strongly disagree, $10.0 \%$ disagree. This can be attributed to the loss of livelihood due to attacks and damages caused by wildlife animals. 
A. L. A., SHOTUYO, O. A., AKINTUNDE AND F. G LANLEHIN

Table 7: Distribution of Respondents according to assessment of impacts of Human Wildlife Conflicts

\begin{tabular}{llllll}
\hline RESEARCH QUESTION & SA & A & SD & D & TOTAL \\
& $\mathbf{F ( \% )}$ & $\mathbf{F ( \% )}$ & $\mathbf{F}(\%)$ & $\mathbf{F}(\mathbf{\%})$ & F(\%) \\
\hline Decrease revenue from crop damaged & $39(48.8)$ & $13(16.3)$ & $19(23.8)$ & $9(11.3)$ & $80(100)$ \\
$\begin{array}{l}\text { Increase risk of starvation as there is no } \\
\text { food due to loss of farm produce }\end{array}$ & $37(46.3)$ & $14(17.5)$ & $22(27.5)$ & $7(8.8)$ & $80(100)$ \\
$\begin{array}{l}\text { Raising orphans is difficult due to con- } \\
\text { flict incidents }\end{array}$ & $40(50.0)$ & $12(15.0)$ & $23(28.7)$ & $5(6.3)$ & $80(100)$ \\
$\begin{array}{l}\text { Residue from crops is not returned to } \\
\text { soil as fertilizer when they are eaten }\end{array}$ & $40(50.0)$ & $12(15.0)$ & $24(30.0)$ & $4(5.0)$ & $80(100)$ \\
$\begin{array}{l}\text { Means of livelihood of villagers is de- } \\
\text { stroyed }\end{array}$ & $43(53.8)$ & $14(17.5)$ & $18(22.5)$ & $5(6.3)$ & $80(100)$ \\
$\begin{array}{l}\text { Extinction of wildlife animals due to } \\
\text { hunting and indiscriminate killing }\end{array}$ & $43(53.8)$ & $15(18.8)$ & $14(17.5)$ & $8(10.0)$ & $80(100)$ \\
\begin{tabular}{l} 
Creates unemployment \\
\hline
\end{tabular} & $44(55.0)$ & $17(21.3)$ & $11(13.8)$ & $8(10.0)$ & $80(100)$ \\
\hline
\end{tabular}

Perception of Respondents on the Control of Human Wildlife conflicts in Surrounding Villages

About $32.5 \%$ of the respondents strongly agree that if monkey or Baboons, they will deal with them, $17.5 \%$ agrees, $29(36.3 \%)$ strongly disagree and $13.8 \%$ disagrees (Table 8). This can be connected to the fact that most of the rural dwellers are not permitted to kill the monkeys and baboons. This conforms to the findings from Pers.Com. (2010), which noted that discussants emphasized that "Wild animals especially Kirka (Tantalus Monkeys) has disturbed their village for a long time as they are not permitted to kill the animals. About $47.5 \%$ of the respondents strongly agree that beating drums chases them (wild animals) away, $33.8 \%$ agree, while $8.8 \%$ strongly disagree and $10.0 \%$ disagree. This finding is in line with the study of Byamukama and Asuma (2006), who noted that the beating of drums and shouting causes

Gorillas in Bwindi impenetrable National Park to retreat from cultivated and residential areas. Also $48.8 \%$ of the respondents strongly agree that setting fire on the park range borders chases wildlife away from villages, $31.3 \%$ agree, $7.5 \%$ strongly disagree, $12.5 \%$ disagree. This result of majority setting fire on the park border area conforms with the findings of Campbell, (2007) who noted that effectiveness of the use of fire as not be evaluated and that fires are problematic as uncontrolled bushfires endanger people and wildlife animals. About $53.8 \%$ of the respondents strongly agree that they contact extension agents or range management in the case of wildlife attack incident, $30.0 \%$ agree, $5.0 \%$ strongly disagree, $11.3 \%$ disagree. This indicates that on the occasions of attack by wild animals, park rangers and extension agents are called to control such incidence. Also $57.5 \%$ of the respondents strongly agree the use of scare crows on farmland, $26.3 \%$ agree, $6.3 \%$ strongly disagree, $10.0 \%$ 
disagree. About $48.8 \%$ of the respondents strongly agree that while waiting for park rangers, we make noise to scare animal away, $31.3 \%$ agree, $7.5 \%$ strongly disagree, $12.5 \%$ disagree. This finding is in line with the study of Byamukama and Asuma (2006), who noted that the shouting causes Gorillas in Bwindi impenetrable National Park to retreat from cultivated and residential areas. Also $46.3 \%$ of the respondents strongly agree that fixing or maintaining fence helps control human wildlife conflicts, $23.8 \%$ agree, $18.8 \%$ strongly disagree, $11.3 \%$ disagree. Majority agrees they fix fences to control attack of wildlife attack. But findings by Ohashi, (2005) reveal that in Bossou Guinea, Chimpanzees have learned to dismantle wire snares by triggering the release mechanism without contacting the snare. Forty-five percent of the respondents strongly agree that there is no barrier between people and the park, 25.0\% agree, $22.5 \%$ strongly disagree, $7.5 \%$ disagree. This can be attributed to the lack of fences constructed by the park management, thereby facilitating the free flow of wildlife animals into surrounding communities. Also $46.3 \%$ of the respondents strongly agree that giving consideration to the surrounding villages interest (dialogue) helps control human wildlife conflicts, $31.3 \%$ agree, $13.8 \%$ strongly disagree, $8.8 \%$ disagree. This indicates that if the respondents are given due consideration, human wildlife conflicts can be controlled and reduced as conflict between rural dwellers and the community can be resolved. Also 46.3\% of the respondents strongly agree that use of repellents helps control human wildlife conflicts, $30.0 \%$ agree, $15.0 \%$ strongly disagree, $8.8 \%$ disagree. This is in line with the findings of Strum, (1994) and Chalise, (2001) who noted that crop palatability by applying capsicum solution has help to chase wildlife animals for eating crops.

About $48.8 \%$ of the respondents strongly agree the use of bee hives, $28.7 \%$ agree, $11.3 \%$ strongly disagree, $11.3 \%$ disagree. Majority of the respondents believes that the bee's hives will pose as a threat to the wildlife animals attack their crops in the process chasing them away. In addition $37.5 \%$ of the respondents strongly agrees that the cultivation of non palatable crops and use of baboon urine as control, $27.5 \%$ agree, $20.0 \%$ strongly disagree, $15.0 \%$ disagree. The result shows that planting of such crops will drive wildlife animals away from the rural dwellers farmland as they will visit other area for food. Also $30.0 \%$ of the respondents strongly agree that translocation (trapping and moving of problems animals, also people) helps control human wildlife conflicts, $28.7 \%$ agree, $23.8 \%$ strongly disagree, $17.5 \%$ disagree. The result shows that translocation of problem animals will help in reducing the damages and loss of revenue due to attacks of such animals. In addition $11.3 \%$ of the respondents strongly agree that guarding of farmland helps control human wildlife conflicts, $20.0 \%$ agree, $47.5 \%$ strongly disagree, $21.3 \%$ disagree. This shows that majority of the respondents strongly disagrees as they believe they cannot watch over the farm all day as they have other household activities. Also $30.0 \%$ of the respondents strongly agree that use of lethal weapons (killing of problem animals) helps control human wildlife conflicts, $25.0 \%$ agree, $32.5 \%$ strongly disagree, $12.5 \%$ disagree. This shows that if lethal weapons are used wildlife animals encroaching farm land will be chased away from damaging crops. 
Table 9: Test for significant relationship between the socioeconomic activities of the respondents and the impact of human wildlife conflict on the people in the surrounding communities and wildlife

\begin{tabular}{lllll}
\hline Variable & Value & DF & Asymp Sig. & Decision \\
\hline Age & 41.134 & 4 & 0.636 & NS \\
Sex & 13.513 & 4 & 0.563 & NS \\
Marital Status & 14.306 & 4 & 0.993 & NS \\
Religion & 94.849 & 4 & 0.000 & S \\
Educational Level & 77.192 & 4 & 0.002 & S \\
House Size & 17.405 & 4 & 0.295 & NS \\
Occupation & 57.597 & 4 & 0.099 & NS \\
Income & 46.587 & 4 & 0.407 & NS \\
\hline
\end{tabular}

Test for significant relationship between the socioeconomic activities of the respondents and the impact of human wildlife conflict on the people in the surrounding communities and wildlife's

There was a significant relationship between the Religion, Educational level of the respondents and the impact of human wildlife conflict on the people in the surrounding communities and wildlife's as the significant level is less than 0.05 (Table 9). The result shows the religious belief of the respondents has effect on the impact of human wildlife conflicts as some of the respondents believes that some parts of the wildlife animals can be used for fetish worship and in the case of attack on their farmland they kill them and used or sell them out to traditionalist.

Also a relationship exists between the educational qualification of the respondents and the impact of human wildlife conflict on the people in the surrounding communi- ties and wildlife's. This can be attributed to the fact that the educational level determines the level of management of conflicts between human and wildlife. This result is in line with the earlier findings of Oduntan $e t$ al (2008) who noted that majority of the respondents in his study area were without formal education. Past researchers have found that farmers with formal or higher education level are more likely to recognize and be cautious of harmful environmental practices or pest control methods and management of human wildlife conflicts. (Jacobson et al, 2006).

\section{CONCLUSION}

The study revealed that majority of respondents; in the neighbouring villages of Old Oyo National Park are farmers and married. It also revealed that due to the loss of several amount of money amounting to thousands of naira due to damages caused by wildlife animals such as primates, warthogs and others on their farmlands, the farmers however 
resulted into use of fire arms and traps to mitigate and control these damages on their own farmlands. This shows that the villagers don't believe in conservation of the wildlife as they have tolerated the activities and destructions caused by the species over the years without any form of compensation.

It could also be concluded that due to the abundance of food in the area the destructions by Tantalus monkey would not seize, as most of the crops produced are consumed by the wildlife. And food would always be abundant because of the high fertility of the soil along the river basins coupled with the fact that the agrarian households are continuously cropping at least 3 times in a year. It could however be concluded that the non - payment of compensation and the poor fencing of the park in restricting the movement of the wildlife is sole responsible for Human wildlife conflict. Due to the lack of commensurate means of compensating the people is not put in place as the pressure is continuously building up the resultant conflict will become frequent and complex to manage.

The study also revealed that the presence of Fulani cattle rearers attracted by the luxuriant vegetation in the park whose cattle have been vandalizing crops of farming households and grazing on vegetation meant for wild games, which exposes the wildlife's to their farms. This has resulted in loss of farm and poor capital returns.

It could also be concluded that due to the Human wildlife conflict, this which has generated a negative fillings about Tantalus monkey and the villagers has resulted in killing the species secretly using poisons, traps and gun.

\section{RECOMMENDATION}

In mitigating the occurrence of humanwildlife conflict, there is need to take into consideration some of the findings of this study, the following recommendations are made

Conservation education for local population at different levels to disseminate innovative techniques, building local capacity in conflict resolution and more understanding of $\mathrm{Hu}-$ man -Wildlife Conflict (HWC). This will promote commitment towards conservation.

Promotion of dialogue and cooperation among different stakeholders. The commitment and coordination of local governments, National Park Service, Non-Governmental Organization (NGOs), conservation organization, scientific community, tourism and rural people will enhance participation, support and more contribution towards conservation activities.

Integration of the village council in management process to create better understanding between the Park and the local communities. Construction and maintenance of bridges, culverts, roads and tracks to ease movement of people and farm produce.

Employment of more youths of the area to increase local involvement.

Construction of permanent ranger's post in Mayo Yum guard against illegal grazing in the Park.

\section{REFERENCES}

Chalise, M.K. 2001. Crop raiding by wildlife, specially primates and indigenous knowledge of food conservation. Asian Primates 7 (3-4): 4-9. 
Choudhury, A. 2004. Human-Elephant Conflicts in Northeast India. Human Dimensions of Wildlife 9: 261-270.

Distefano, E. 2004. Human-wildlife conflict worldwide: collection of case studies, analysis of management strategies and good practices. Rome, FAO.

Dublin, H.T., Hoare, R.E. 2004. Searching for Solutions: The Evolution of an Integrated Approach to Understanding and Mitigating Human-Elephant Conflict in Africa. Human Dimensions of Wildlife 9. 413

Emerton, L. 1999. Balancing the Opportunity Costs of Wildlife Conservation for Communities Around Lake Mburo National Park, Uganda. Evaluating Eden Series no 5, IIED, London, U.K.

Happold, D.C.D. 1995. Interactions between humans aand mammals in Africa in relation to conservation: a review. Biodiversity Conservation 4 (4): 395-414

Hill, C., Osborn, F., Plumptre, A. J. 2004. Human-Wildlife Conflict: Identifying the Problem and Possible Solutions. Albertine Rift Technical Report Series Vol.1. Wildlife Conservation Society, Kampala pp. 23-35.

Jacobson, S.K., M.D., McDuff., M.C. Monroe 2006. Conservation education and outreach technologies. Oxford University Press, Oxford, United Kingdom.

Kirk - Greene, A.H.M. 1958. Adamawa Past and Present. Oxford University Press, London, pp. 1 - 23.

McGregor, S. 2005. Structural adjustment programmes and human well-being. Interna- tional Journal of Consumer Studies, 29: 170-180. doi:10.1111/j.1470-6431.2005.00383.x.

Naughton - Treves, L. 1998. Predicting Pattern of crops damage by wildlife around Kibale National Park, Uganda. Conservation Biology, 12:156 - 168.

Naughton - Treves, L., Treves, A., Chapman, A.C., Wragham, R.1998. Temporal pattern of Crop - raiding by Primate: Linking food Availability in Crop land and adjacent forest. Journal of Applied Ecology 35:595 - 606.

Newmark, W. D., Manyanza, D. N., Gamassa, D. M., Sariko, H. T. 1994. The Conflict between Wildlife and Local People Living Adjacent to Protected Areas in Tanzania Human Density as a Predator. Conservation Biology 8:249-255.

Oduntan O.O., Ojo V.A., Odunaiya O. 2008. Conservation legislation and wildlife offences in old Oyo national park: contribution of stakeholders, Obeche Journal, 27(1): 5965.

Oduntan O.O., Akinyemi A.F., Ayodele I.A. 2009. Attitude of farmers to wild animals in Hadejia-Nguru wetlands: causes and implications, Obeche Journal, 28(1): 12-16.

Oduntan O.O., Akintunde O.A., Oyatogun M.O.O., Shotuyo A.L.A., Akinyemi A.F. 2012. Proximate composition and social acceptability of sun-dried edible frog (Rana esculenta) in Odeda local government area, Nigeria, Production, Agriculture and Technology (PAT) June, 2012; 8 (1): 134 -143; ISSN: 0794-5213A.

Porter, P.W., E. S. Sheppard 1998. A World of Difference: Society, Nature, Development New York: Gilford Press. 
IMPACT OF HUMAN-WILDLIFE CONFLICT IN THE SURROUNDING VILLAGES...

Rowe, N. 1996. The Pictorial Guide to the Living Primates Pogonias Press, New York: 150-151.

Shemweta, D. T., Kidegesho, T. R. 2000. Human Wildlife Conflict in Tanzania: What Research and Extension could offer to Conflict Resolution. Proceedings of the 1 st University Wide Conference 3: 569-576.

Strum, S.C. 1994. Prospects for management of primate pests. Revue d' Ecologie (Terveet Vie) 49: 295-306

Treves, A., Karanth, K.U 2003. Humancarnivore conflict and perspectives on carnivore management worldwide Conservat Int, Ctr Appl Biodivers Sci, Madison, WI 53705 USA; Wildlife Conservat Soc, Int Programs, Bronx, NY 10460 USA.

UNICEF 2006. State of the world's children New York.

Warren, Y. 2003. Olive Baboons (Papio anubis): Behaviour, Ecology and Human Conflict in Gashaka Gumti National Park, Nigeria. Unpublished $P h . D$ Thesis University of Surrey.

Waladji, R.B., Tchamba, M.N. 2003.
Conflict between people and protected area within the Benoue Wildlife Conservation Area, North Cameroon, Oryx 37: 72-79

WCS 2010. Wildlife Conservation Society Newsroom (www.wcs.org) Assessed 25 $5^{\text {th }}$ May 2017.

Woodroffe, R. 2000. Predators and people: using human densities to interpret declines of large carnivores. Animal Conservation, 3: 165-173. doi:10.1111/j.14691795.2000.tb00241.x.

Woodroffe, R., Lindsey, P., Romanach, S., Stein, A., Ranah, S.M.K. 2005. Livestock predation by endangered African wild dogs (Lycaon pictus) in northern Kenya, Biological Conservation 124, 225-234.

Yudelman, M., Ratta, A. Nyguard, D. 1991. Pest Management and Food Production, Agriculture and the Environment: Discussion paper 25. International Food Policy Research Institute, Washinghton, D.C., USA.

WWF 2005. Resources for implementing the WWF project and programme standards Cross Cutting Tools: Conceptual Models. WWF Gland, Switzerland.

(Manuscript received: 6th June, 2017; accepted: 11th March, 2021). 